\title{
Contested Wealth: Social and Political Mobilisation in Extractive Communities in Africa
}

\section{Introduction}

In September 2017, riots broke out in the Guinean towns of Boke and Kamsar, one of the country's centres of bauxite production. Residents took to the streets to protest the pollution produced by the mines and the constant electricity cuts they experience, in an area where the vast majority of power is consumed by mining companies jointly owned by the Guinean state and by Western and Chinese investors. ${ }^{1}$ One person was killed, at least twenty injured and bauxite production was halted as anti-riot police were deployed and negotiations were launched to seek a solution to the problem. ${ }^{2}$ This was the latest in a wave of protests that first erupted in April 2017: one of the victims of those riots, shopkeeper Mohamed Camara, told a journalist: "This is the fault of the state. We have all the mining, and no electricity". Local resident Lamine Banoro told Reuters he had sent his CV to the mining companies but had no success obtaining employment: "There are big mining companies here, yet no one who is a native to Boke can get a job. Even the Guineans getting jobs come from outside Boke". While mine companies claimed the unrest was not directly caused by their operations, Mines Minister Abdoulaye Magassouba admitted: "There is a legitimate frustration but it cannot justify violence ... Our challenge is to reassure people that every job that can go to a Guinean will. We also plan ... to better use our revenues to develop these zones, so people can see the impact". ${ }^{3}$

These recent events in Guinea exemplify not only the types of protests and mobilisations that are examined in this special section, but also the divisions within extractive communities and between such communities, mining companies and their states. When 
proposing the category of 'extractive community' for the conference panel that led to this set of articles, our aim was to problematize and bring into comparative analysis a set of issues affecting parts of Africa where extractive industries operate, but which are commonly analysed separately with unhelpfully normative frameworks: for example, the treatment of industrial-scale and artisanal extraction as inherently distinct; the position of workers employed to extract minerals and communities affected by them; and the separate analysis of specific divisions within extractive communities - class, gender, generational, racial and ethnic - in processes of social change and conflict. While extractive communities are clearly influenced by their engagement with economically and geo-politically significant minerals, they also have the capacity to shape their exploitation, its wider effects, and the distribution of the wealth they generate. The articles in this special issue demonstrate that placing extractive communities at the centre of our analysis helps overcome some of the limitations imposed by other ways of approaching the exploitation of mineral wealth in recent African history until today.

\section{Historicising extractive communities}

Much historical analysis of mineral extraction in Africa implicitly associates such exploitation with the imposition of colonial rule and the establishment of western-controlled mining companies, whose authority to seize territory and exploit it regardless of local claims rested on their colonial connectivity. If we take a longer view, to encompass for example the centuries-long extraction of gold in west and southern Africa and its sale into trans-Saharan, South Asian and Chinese markets, or the ways in which copper mining partly fuelled the rise of some of central Africa's savannah kingdoms in the $17^{\text {th }}$ and $18^{\text {th }}$ centuries, then we can 
better appreciate both the continuities and breaks between indigenous and colonial forms of mineral exploitation. Here, and in the Asante kingdom, Great Zimbabwe and Mapungubwe, mineral extraction and trading enabled the establishment of powerful states, able to convert that wealth into political hierarchy, the conquering and/or incorporation of neighbouring societies, and the exploitation of unfree or subject labour. The concentrated nature of mineral wealth has always enabled its possessors to accumulate wealth in a relatively portable form, but that wealth was also dependent on accessing and controlling trade routes and on realising its fluctuating value in global markets. Colonial annexation shattered many of those trade routes and redirected them along different routes controlled by Europeans, though African challenges to that control were ever present.

Colonial-era industrial mining certainly looked different to its pre-colonial predecessors and was commonly perceived by Western observers as a qualitatively new, modernising process that brought new technologies and industry to the African 'interior' and supposedly integrated these areas into the global economy for the first time. In reality, colonially connected mining companies required the capacity of colonial states to displace and reorder indigenous communities, precisely because those communities had their own ideas about those minerals and the land under which they lay. Turning deposits of gold, copper or diamonds into profit meant altering the legal ownership and the cultural meaning of land. As Frederiksen (2013) argues, colonial-era mining developments were constituted as 'scientific' projects involving the imposition of a colonial production of knowledge on the African landscape. All such processes required economic, political and cultural investment, each of which had to be negotiated and each of which was contested in unpredictable ways that ultimately shaped its outcome. 
Of equal importance to land alienation was the harnessing of African labour power for the extraction of minerals, which involved unfree labour of various kinds. Authoritarian labour regimes were established in colonially connected mining centres, though they were limited in effect: aspirant workers commonly succeeded in evading labour controls. The migration organised, 'spontaneous' or somewhere in-between - of workers to mining locations was usually necessary, but the documentation of this process was distorted by a structural Marxist emphasis in a dual model of migrant labour vs a working-class in the making. In practice, mine work was, for most Africans, commonly conducted alongside non-mine work, particularly agricultural activity, and could itself be seen as a seasonal activity for many of those concerned: mine companies, for example in the Belgian Congo, sometimes used contractors to develop mine sites on their behalf (Vellut, 1981). Structural Marxists tended to see such 'migrant labour' systems as a 'beta' version of the African working-class they desired to locate and explained it in terms of its deficiencies or distortions in relation to an idealised proletariat, conceptualised in relation to a particular reading of the West's history of industrialisation and the birth of its working-class (Larmer, 2017).

The racial categorisation and segregation of mine workforces was equally central to colonial notions of labour: migrant workers from the Western world were employed on an entirely different basis to their African migrant counterparts and the former often accepted and reinforced this division. Yet, as Duncan Money argues in his article on white mineworkers in Northern Rhodesia, it should not be assumed that 'race' was always the primary 'category of difference' (Brubaker, 2015: 18) in the conscious thinking of such workers, or even their mining communities. According to Money, white mineworkers in Northern Rhodesia 
emphasised their exploitation by and antagonism to mining capital in the political language of global communism and socialism and - notwithstanding their extraordinary privilege, resting as it did on a contractual colour bar - saw themselves primarily through the prism of class rather than race. Money's findings have relevance for today's deeply hierarchical mine labour forces in which senior, internationally recruited and racially heterogeneous skilled workers remain strikingly segregated - residentially and in the provision of support services) from a larger, less skilled and often casualised workforce recruited from the locality and nearby.

In their efforts to produce a usable workforce, many mine companies built new mine townships (see also below) and provided health and welfare services. Over time, and sometimes with the prompting of organised labour and late-colonial and post-colonial states, residential and educational services were provided that enabled some workers to accommodate their families in what evolved into towns. While today there is in some extractive communities a pronounced nostalgia for a golden age of corporate paternalism, company towns were - as Udelsmann Rodrigues demonstrates here for Angola - sites primarily designed to control and discipline labour. Company towns were also inherently exclusionary places that sowed or reinforced divisions: between company town residents and those (mainly women) who were not formally employed by mines but who provided services to these communities; between urban and rural communities linked to mine towns by remittances, migration, and ideas; and - in some cases - between ethnically constituted groups placed in competition for jobs and services. Like mine companies themselves, researchers have often been guilty of privileging organised (usually male) labour over other members of extractive communities, both because of a primary focus on the assumed role 
of organised labour and because of their greater archival legibility. If we step away from an institutional approach it quickly becomes clear that, while mine communities may see themselves as having unified interests opposed to mine companies, they are themselves marked by significant divisions - racialised, gendered, generational, ethnic and educational, for example - and should never be assumed to have inherently shared interests. Nor however should the meaning of more visible divisions be assumed: although industrial mineworkers with employment contracts may benefit from the exclusion of artisanal miners who seek control of some of the same resources, they may equally be members of the same extended family networks, and indeed be the same individuals whose circumstances have changed, with the ebb and flow of markets and investments and related employment opportunities over time (Rubbers, 2006: 117; Cuvelier, 2017: 180-1).

\section{Fixed workplaces and mobile communities}

If we challenge the primacy of production, or expand our definition to encompass the production of livelihoods, meanings and societal relations, then we can then see that other aspects of economic or social activity in mine communities, or areas linked to them by migrations, remittance flows and the supply of resources, are as influential and therefore worthy of analysis on outcomes (Ferguson, 2015). This raises the complex question addressed by some of our contributors - of where to draw the boundaries of what an extractive community consists of. In this volume, Maha Rafi Atal suggests that attempts to understand conflicts in Lonmin's platinum mining areas in South Africa have focused primarily on workplace dynamics, thus failing to appreciate the wider community in which various stakeholders - particularly local residents with no formal link to the mine - engage with and challenge company activities, particularly as they affect land usage. 
Many analysts, sometimes for practical reasons but also for ideational ones related to assumptions, have previously drawn artificial analytical lines around mine townships and workplaces that excluded rural sending areas, especially when the latter were in 'foreign' countries. As Carini demonstrates in this volume, migrant 'sending' communities in Mozambique are a vital part of understanding the dynamics between migrants and selfdeclared autochthons in South African gold mines, but - with a few honourable exceptions have often gone unrecognised or been analysed separately from the 'mainstream' nationally constituted workforce. Carini's work builds on the more historical research of the late Patrick Harries to analyse post-Apartheid Mozambican mineworkers in situ in their South African workplace, in relation to their home areas in Mozambique and in transit, in the regulatory environment of the border between the two countries (Harries, 1994).

In general however, the academic examination of fixed geographical mining/non-mining space - conceptualised and imagined as counterposed urban vs rural places - has often failed to capture the holistic experience of migrant mining communities who continued to move from place to place, utilising a range of livelihood options over time. The governance of mining space involves shifting legal norms - for example a change from corporatist control of vast land areas to which some colonial-era mine companies laid claim, to neoliberal models of thin corporations that reduced their footprint to the area of the mine only. These need to be understood as ideological constructions, in which companies and investors seek to project a normative model of exploitation so as to claim or refute certain rights and/or responsibilities for the land and people vital to their operations. 
In this respect, industrial mining areas constructed as male were occupied by large numbers of women, rendered invisible by policy but in practice a vital part of extractive communities: women who were excluded from mineral production grew food which fed mineworkers and provided other vital entrepreneurial and reproductive services, whether they were resident in 'rural' areas of origin or in 'urban' mining towns (Larmer 2017: 176-7). In artisanal mining, masculinity has often been defined by the development of skills and a personal definition of 'craftsmen' who could provide for their families, but men's capacity to establish this status was fragile and rested on highly contested access to production sites and external markets. In some places, for example Lesotho, women play a significant role in the process of artisanal mining carried out in close proximity to rural communities (Makhetha, 2013). In all cases, mining communities are spaces in which gender identities and sexual relations have developed in both commodified and affective ways (Fahy Bryceson et al, 2013).

Less well documented but equally central are generational dynamics and the capacity of youths to make the transition to adulthood via new means, either paid employment or cash paid for artisanal production. This destabilised rural patterns of generational relations, potentially allowing young men to achieve high status via visible enrichment - as documented for some formally employed mineworkers in the early-to-mid twentieth century - or, in areas of mineral production where that wealth is largely absent, of fuelling generational conflict. In this volume, Iwilade focuses on generational divisions in the Niger Delta in a context where the achievement of respectability, so often undermined by the extraction of wealth with no noticeable benefit to local communities, is pursued by youth social networks in ways that ultimately incentivise violence as a path to social adulthood. Rather more positive findings are reported by Roy Maconachie, whose work on post-conflict 
Sierra Leone demonstrates that youth activism, in response to grievances arising from the limited opportunities arising from artisanal diamond mining, is opening up new opportunities for public engagement in policy-making in an economy still dominated by the perilous extractive-based path to development.

\section{Company governance and its discontents}

Historically, the effective exploitation of mineral resources required the concentration of wealth, science and labour in towns - once African populations began to establish themselves in these places (while remaining linked to rural areas of origin), they began making social and economic demands that were predicated on extractives' potential for wealth generation and differential distribution and which intersected with nationalist demands in complex ways. Late colonial and post-independence models of developmentalism, whilst at the same time increasing compensation for workers, drove demands for higher productivity and reductions of the scale of the labour force, a process that continues in various forms today. From the 1990s and with the onset of fully fledged neo-liberalism, liberalisation often occurred in consort with economic decline, leading to the wholesale reduction of formal sector jobs and the 'cradle to grave' welfare services sometimes associated with them. Simultaneously there was a rise in artisanal mining, often associated with conflict (see below) but which may also be interpreted as reflecting the driving down of the costs of mining by replacing unprofitable organised industry with illegal, unregulated extraction that passed on most of the costs to the workers and communities affected. Industrial-scale mining reasserted itself in some places with the Chinese-fuelled boom from the mid-2000s: now the neo-liberal setting created the possibility of MNCs operating without, as they saw it, the costly burden of community production/reproduction, 
and by outsourcing much of the work to contractors, the latter often employing former mineworkers on lower pay and casual contracts. While mine companies may seek to 'enclave' their activities, communities continue to challenge their attempts to do so, but not necessarily in unified ways (Ferguson, 2006; Laterza, 2016; Kesselring, 2017).

This has however been widely contested: existing and new mine communities have demanded that companies take responsibility for the social costs of extraction and/or that some of the proceeds of mining accrue to them. In a context of reduced formal mine employment resulting from mechanisation and skilling, the benefits from mining may come in forms less tied to wage employment, and may also involve demands that companies pay for the social and environmental costs of their activities. Political elites have sometimes welcomed new investment while downplaying or suppressing such resistance, but on other occasions have sided with communities and occasionally played populist cards to good effect, when attacking Chinese or Indian investors (Larmer and Fraser, 2007; Fraser, 2017). Contemporary mine companies, unlike many of their colonial-era predecessors, have had to engage not only with nation-states but also a well-established set of traditional authorities with governance rights over the land under which minerals lie and problematic claims to represent extractive communities themselves. This can and has led to the interpretation of 'community interests' as the construction of palaces for chiefs and the provision of jobs for royal retainers, fuelling intra-community disputes and tension between 'residents' and 'migrant workers' in such areas. In South Africa's platinum belt this has resulted in lengthy legal disputes about the Bapo Ba Mogale royal family's right to speak for the communities in negotiations with companies (Capps, 2012 and 2015; Manson, 2013). Patience Mususa's current research explores the complex power relations in Zambia's 'new' Copperbelt, 
involving chiefs, national officials, non-governmental organisations and companies (Mususa, 2016). In this collection, Sara Geenen and Judith Verweijen demonstrate that the 'hyperfragmented and fluid' forms of social mobilisation they analyse in gold mining areas in the eastern Democratic Republic of Congo reflect myriad divisions of these types, shaped as they are by the complex interplay of diverse political forces from above and below.

Attempts by new mine companies to impose innovative new forms of spatial authority, then, simultaneously build on and contrast themselves with older models of company towns. Maha Rafi Atal, whose wider research analyses the role of private companies as providers of 'public' goods and services', explores in this volume the provision of welfare services as the basis of conflict both between Lonmin and local stakeholders, and between the many sections of its extractive community, over what is deemed the right kind of corporate governance. Cristina Udelsmann Rodrigues, in her analysis of the diamond mining Lunda provinces of Angola, contrasts the historically hegemonic authority of company control over mining towns during the colonial and wartime periods to 2002 , with the contemporary environment. Today, attempts by the Angolan state, and diamond miners such as Catoca, to create new centralised mining towns, provide opportunities for communities to engage with and contest the power dynamics within these projects and, in particular, the specific provision of welfare and social services envisaged by these dominant actors.

\section{Beyond 'resource curses' and greed vs grievance}

Mining in Africa, as elsewhere, clearly has contributed to the growth and entrenchment of social division, political conflict and economic inequality. It may also - though the point is 
less often made - contribute to the increase in living standards and the earning of income by states and workers. It has never done so, however, in isolation from more significant political and social factors: neoliberal states, mine companies and non-state actors 'curse' Africa, resources do not (Auty, 2002).

Likewise, the notion that the likelihood of mineral-linked conflict in Africa can be usefully understood via a 'greed vs grievance' binary framework has generally been shown to be a fallacy, partly because it also tends to assume that there are self-evidently legitimate and illegitimate ways to extract and exploit mineral wealth (Collier and Hoeffler, 2000). While some extractive projects can be observed to be more beneficial than others, it is not evident that for example industrial-scale mining carried out by multi-national companies in legal contractual arrangements with nation-states, in which CSR processes have been completed, necessarily bring more benefits to extractive communities than illegal or semi-legal extraction projects. Artisanal mining may reflect conflictual surroundings, may enable the extraction of resources from areas at well below its market rate and may have damaging environmental and social consequences, but the same can be said for industrial-scale mining. Artisanal mining, commonly associated with poor safety conditions, illegality and environmental damage, may offer the least worst way in which some element of mineral wealth can 'trickle down' to some members of extractive communities: states and companies have their own reasons for regulating or preventing their activities, many of which may make such trickle down less likely. Nor should the link between artisanal mining and violence go unchallenged: industrial-scale mining companies have often used their own security forces and those of host states to repress opposition to their activities. It may be noted that the Marikana massacre, one of the most violent repressive acts ever carried out 
in a postcolonial African mining community, was the act of the police force of a constitutionally liberal democratic country, of workers employed by the UK-based multinational Lonmin, a company with clearly documented CSR policies and recognition agreements with that country's National Union of Mineworkers (Alexander et al, 2012).

\section{Extraction without growth: Political and social mobilisation in a global context}

What becomes clear from such analysis is that understanding political and social mobilisation among extractive communities is never simple. On the one hand, there often are clear differences between the interests of communities and those of extractive companies, which have generally opposed aims regarding the desirable use of mineral revenue. Political mobilisation of unionised mine labour and conflict with late-colonial and post-colonial states; new constructions of mine capital under nationalisation and then privatisation; and swings in global economy affect different minerals differently, but the colonial legacy of 'underdevelopment' tends to prevent African communities ever gaining effective control over mineral wealth and directing it for development. In the twenty-first century, this is reinforced by massive global tax evasion and avoidance by mine companies (United Nations Economic Commission for Africa, 2016), meaning that contestation over which local actors benefit from extractive activity - central state vs local government, workers vs residents, elders vs youth, autochthons vs migrants, and so on - amounts to an unedifying scrap over leftovers.

While the 2007-2008 financial crisis had a limited effects on African markets, due in significant part to sustained demand for extractives in China and other emerging economies, since 2015 a global slump in mineral demand has had a negative effect on African 
economies. It has badly affected countries that - despite efforts at diversification - remain heavily reliant on extractives, such as Nigeria, Angola and Zambia. Mass retrenchments have taken place, there have been drastic reductions in government revenue and the stalling of, for example, new natural gas projects in countries such as Mozambique and Tanzania.

Beyond the inevitable short-term fluctuations, analysts generally agree that this is an uncertain moment and predictions about future trends are more difficult than ever. Geopolitical factors such as the contestation of free market neoliberal orthodoxy in some Western countries, make the scenario particularly unstable. Recent literature on the economics of energy and mineral investment highlights that energy returns on investment are constantly declining, and suggests that we are rapidly approaching peak oil - and peak minerals - a situation where extracting more fossil fuels and more minerals becomes increasingly more costly, spurring a permanent and irreversible decline in profitability. This in effect would mean that the global economic growth witnessed from the end of $19^{\text {th }}$ century until the 1970s might be over (Ahmed, 2017; May et al, 2012). There is much work to be done to empirically explore this hypothesis in the African context and beyond, but these are conceptual frameworks that surely deserve more attention than they have received thus far.

This modern economic development in the global north was largely driven by the availability of cheap energy and raw materials to drive industrialisation and redistribute the wealth produced in a virtuous cycle that overcame economic dualism (Lewis, 1977). Africa was largely excluded from this, or rather, it fuelled this growth while reaping few benefits from it - we can see colonialism and the continued exploitation of Africa's resources by 
multinational capital as distinct legal-political regimes that enforced economic dualism up to the present day.

The growing instability of Western and global politics, with populist parties utilising antiestablishment rhetoric, has a direct impact on the fragile relations between states, markets and societies in Africa, and extractive communities find themselves at crucial conjunctures in these systemic imbalances and intensifying social and political struggles for resources.

There is no sign that African states are today better equipped to mount a challenge to the rule of multinational capital than in the recent past. Indeed, state actors often facilitate unfair deals that negatively affect communities, citizens and the environment, encouraging new forms of corruption and malpractice across the continent. Despite rhetorical statements to the contrary, there is little demonstrable commitment from northern economies to clamp down on this state of affairs. Many African states which have been at the centre of the mineral boom of the 2000s have also borrowed large amounts of money on the international bond markets, and are now struggling - or will soon struggle - with repayments. With diminishing revenues, this debt is clearly unsustainable. The IMF has already started a programme in Ghana, has approved another one in Cameroon, and, at the time of writing, is in negotiations with Zambia. ${ }^{4}$ There is a real risk that public debt, very much like in the 1980 s and 1990 s, will be used to further weaken the negotiating power of states, and could easily lead to further loss of control and wealth from future extractive ventures. 
The sustained economic growth has not only failed to bring substantial benefits to the majority, but also corresponded with further erosion of alternative forms of livelihoods and legal and political systems working on rules and valuations outside the market principle. Costs have risen everywhere, states have not helped local communities to strengthen agriculture and alternative forms of livelihood to wage employment, reduced workforces made the amount of cash available to the wider communities even smaller than before. Despite this, our selection of articles show that communities have responded in a number of ways, and resilience and the capacity to adapt to a highly uncertain environment has in some cases increased. ${ }^{5}$ While it is crucial to highlight inequalities in structural trends, it is equally important to avoid falling into a narrative that posits Africa and Africans as passive victims of international forces, with no active agency countering these trends and building their own sense of dignity and belonging in admittedly adverse conditions (Laterza and Sharp, 2017).

The resurgence of various forms of social and political mobilisation built around ethnicity, traditional ideologies, gender, race and work identities needs to be understood in the context of increased dispossession - and increasing awareness by extractive communities of the negative effects of mining under such conditions. After many large-scale transformative and redistributive social and economic programmes undertaken in the early liberation years, post-colonial states have gone back on the promises made to their citizens at independence, making national liberation more of a symbolic, than an economic process. The weakening of formal representation is resulting in a rise of spontaneous forms in which symbolic and affective dimensions are often the main drivers of complex popular revolts that, while never literally "leaderless", are not easily understood in reference to 
conventional forms of organization such as trade unions and political parties - a dynamic which is certainly not specifically African (see for instance the spread of Occupy movements and Black Lives Matter in North America, among others) (Laterza, 2015).

Karl Polanyi's classic analysis of capital, popular movements and political change certainly helps us frame the current rise in social and political mobilisation as a direct response to the increasing expansion of big capital - and its demands of more for less (i.e. continued presence, less and less redistribution of benefits to locals) (Polanyi, 1944). But Polanyi's work is weak when it comes to understanding the role of identities - e.g. race, ethnicity, gender - in these forms of mobilisation. Understanding that all capitalism is racial and gendered at its origin is key in locating the plight and potentials of African communities interacting with this system (Robinson, 1983; Crenshaw, 1991; Hill Collins, 1991). Inequalities and divisions occur at different levels and scales with regard to gender, the divide between rural and urban places, and the local and global histories of discrimination and conflict between different racial and ethnic groups, among others.

With African states weakened in their potential to redistribute wealth and resources to their citizens and local communities, extractive communities are in practice often mobilised against both multinational giants and powerful national interests.

When it comes to mobilising against the negative effects of extraction, these multiple histories and identities play a crucial role in shaping narratives and imaginations of redress and restorative justice. In a context of increasing state fragility, and erosion of post-colonial national social contracts, understanding these dimensions is key to develop effective economic and political intervention to address the legitimate concerns of local communities. 
While it is true that capital operates in a context of increasing fragmentation, the boundaries of these communities is far from being located in well-defined physical localities, and encompass virtual and physical ties cutting across different national, regional and intercontinental spaces. Emerging social movements forge alliances and networks horizontally, increasing their multi-scalar ties across vast distances, in a way also mirroring the flexible and non-linear logics of multinational capital.

In this fluid landscape, we can find the seeds of alternative forms of governance and sovereignty that are distinct from the current system of state interests closely allied with corporate capital. The current reconfiguration of global capitalism suggests an uncertain future, but it is likely that the struggles for political autonomy and economic improvement waged by extractive communities across Africa will intensify, and they too might produce unanticipated and unexpected political outcomes. What is clear is that established scholarly frameworks to understand and analyse these trends are lagging behind, and we need to do more work to improve empirical descriptions and theoretical analysis of these complex realities. We hope this special section will contribute useful insights in this direction. 


\section{References}

N.M. Ahmed, Failing States, Collapsing Systems: Biophysical triggers of political violence (Cham, Switzerland: Springer, 2017).

P. Alexander, T. Lekgowa, B. Mmope, L. Sinwell and B. Xezwi, Marikana: A View From the Mountain and a Case to Answer (Johannesburg: Jacana, 2012).

R. M. Auty, Sustaining Development in Mineral Economies: The Resource Curse Thesis (London: Routledge, 2002).

R. Brubaker, Grounds for Difference (Cambridge MA: Harvard University Press, 2015).

G. Capps, 'Victim of its own success? The platinum mining industry and the apartheid mineral property system in South Africa's political transition', Review of African Political Economy, 39, 131 (2012), 63-84.

G. Capps (ed.), special issue, 'White Gold: new class and community struggles on the South African platinum belt', of Review of African Political Economy, 42, 146 (2015)

P. Collier and A. Hoeffler, "Greed and Grievance in Civil War," World Bank Policy Research Working Paper 2355 (May 2000), http://papers.ssrn.com/sol3/papers.cfm?abstract_id=630727 (accessed 10 October 2017). K. Crenshaw, 'Mapping the Margins: Intersectionality, identity politics, and violence against women of color', Stanford Law Review, 43, 6 (1991), 1241-1299.

J. Cuvelier, 'Men, mines and masculinities: the lives and practices of artisanal miners in Lwambo (Katanga province, DR Congo ', PhD dissertation, University of Ghent (2011). D. Fahy Bryceson, J. Bosse Jonsson and H. Verbrugge, 'Loosely woven love: Sexuality and wifestyles in gold-mining settlements' in D. Fahy Bryceson, E. Fisher, J, Bosse Jonsson and R. Mwaipopo (eds.), Mining and Social Transformation in Africa: Mineralizing and Democratizing Trends in Artisanal Production (London: Routledge, 2013), 61-78. 
D. Fahy Bryceson, E. Fisher, J, Bosse Jonsson and R. Mwaipopo (eds.), Mining and Social Transformation in Africa: Mineralizing and Democratizing Trends in Artisanal Production (London: Routledge, 2013).

J. Ferguson, Give a Man a Fish: Reflections on the New Politics of Distribution (Chapel Hill NC: Duke University Press, 2015).

J. Ferguson, 'Seeing Like an Oil Company: Space, Security and Global Capital in Neoliberal Africa', American Anthropologist, 107, 3 (2006), 377-382.

A, Fraser, 'Post-populism in Zambia: Michael Sata's rise, demise and legacy', International Political Science Review (2017).

T. Frederiksen, 'Seeing the Copperbelt: Science, mining and colonial power in Northern Rhodesia', Geoforum, 44 (2013), 271-281.

P. Harries, Work, Culture and Identity: Migrant Labourers in Mozambique and South Africa, c. 1860-1910 (London: James Currey, 1994).

P. Hill Collins, Black Feminist Thought: Knowledge, consciousness and the politics of empowerment (New York: Routledge, 1991).

R. Kesselring, 'Disenclaving the Planners' Enclave: The housing project Kabitaka in Solwezi, Northwestern Zambia', blog post on Comparing the Copperbelt project website: http://copperbelt.history.ox.ac.uk/2017/08/21/disenclaving-the-planners-enclave-thehousing-project-kabitaka-in-solwezi-northwestern-zambia-rita-kesselring/ (accessed 10 October 2017).

M. Larmer, 'Permanent Precarity: Capital and labour in the Central African copperbelt', Labor History, 58:2 (2017), 170-184.

M. Larmer and A. Fraser, 'Of Cabbages and King Cobra: Populist politics and Zambia's 2006 Election', African Affairs 106, 425 (2007), 611-37. 
V. Laterza, 'Waves of Unrest: Wildcat strikes and possible democratic change in Swaziland', in K. Hart (ed.), Economy For and Against Democracy (Oxford: Berghahn, 2015), 137-158. V. Laterza, 'Resilient Labour: workplace regimes, globalisation and enclave development in Swaziland', Journal of Development Studies, 52, 4 (2016), 576-590.

V. Laterza and J. Sharp, 'Extraction and Beyond: People's economic responses to restructuring in southern and central Africa', Review of African Political Economy, 44, 152 (2017), 173-188.

A.W. Lewis, The Evolution of the International Economic Order (Princeton: Princeton University Press, 1977).

A. Manson, 'Mining and 'Traditional Communities' in South Africa's 'Platinum Belt': Contestations over Land, Leadership and Assets in North-West Province c.1996-2012', Journal of Southern African Studies, 39, 2 (2013), 409-423.

E. Makhetha, 'Small-Scale Artisanal Diamond Mining and Rural Livelihood Diversification in Lesotho, 'PhD dissertation (2013) University of Pretoria.

D. May, T. Prior, D. Cordell and D. Giurco, 'Peak Minerals: Theoretical foundations and practical application', Natural Resources Research, 21, 1 (2012), 43-60.

P. Mususa, 'Mining, welfare and urbanization: the wavering character of Zambia's Copperbelt', Journal of Contemporary African Studies, 30, 4 (2012), 571-587.

P. Mususa, "'We Were There Before the Mines": Rural struggles and mining investment in North Western Province, Zambia', ASAUK Conference paper, Cambridge (2016).

K. Polanyi, The Great Transformation: The political and economic origins of our time (Boston, Mass.: Beacon Press, 1944).

C.J. Robinson, Black Marxism: The making of the black radical tradition (London: Zed Books, 1983). 
B. Rubbers, 'L'effondrement de la Générale des Carrières et des Mines Chronique d'un processus de privatisation informelle', Cahiers d'Etudes Africaines (2006).

United Nations Economic Commission for Africa, 'Illicit Financial Flow: Report of the High Level Panel on Illicit Financial Flows from Africa' (2016):

http://repository.uneca.org/handle/10855/22695 (accessed 10 October 2017).

J.-L. Vellut, 'Les Bassins miniers de I ancien Congo Belge. Essai d Histoire économique et sociale (1900-1960)'. Les Cahiers du CEDAF, n7, (Brussels: Centre d Étude et de Documentation Africaines, 1981).

\footnotetext{
${ }^{1}$ https://www.reuters.com/article/us-guinea-mining/guinean-protests-halt-bauxite-miner-cbgs-operationsidUSKCN1BU179 (accessed 4 October 2017).

${ }^{2}$ http://africatimes.com/2017/09/13/guinea-new-clashes-erupt-in-boke-bauxite-mining-center/ (accessed 4 October 2017).

${ }^{3}$ http://markets.businessinsider.com/news/stocks/r-one-dead-as-riots-in-guinea-mining-hub-enter-fourth-day2017-4-1001957913; https://www.usnews.com/news/world/articles/2017-05-12/guinea-towns-unrest-acautionary-tale-for-african-mining (accessed 4 October 2017).

${ }^{4}$ https://www.bloomberg.com/news/articles/2017-08-30/imf-approves-one-year-extension-to-ghana-s-creditprogram (accessed 24 October 2017); https://www.imf.org/en/News/Articles/2017/06/26/pr17248-imfexecutive-board-approves-arrangement-under-the-extended-credit-facility-for-cameroon (accessed 24 October 2017); https://www.economist.com/news/finance-and-economics/21723402-falling-commodity-prices-meanloans-are-needed-imf-back-africa (accessed 24 October 2017).

${ }^{5}$ See for instance recent trends in the Zambian Copperbelt after the privatization of the mines: P. Mususa, 'Mining, welfare and urbanization: the wavering character of Zambia's Copperbelt', Journal of Contemporary African Studies, 30, 4 (2012), 571-587.
} 